American Journal of Pharmacology and Toxicology 4 (3):75-79, 2009

ISSN 1557-4962

(C) 2008 Science Publications

\title{
Immunomodulatory and In vivo Antiplasmodial Activities of Propolis Extracts
}

\author{
${ }^{1}$ Syamsudin, ${ }^{2}$ Rita Marleta Dewi and ${ }^{3}$ Kusmardi \\ ${ }^{1}$ Department of Pharmacology, Faculty of Pharmacy, Pancasila University, \\ Jl Srengseng Sawah, Jagakarsa, Jakarta 12460, Indonesia \\ ${ }^{2}$ Research and Development Center for Pharmacy and Biomedicine, Jakarta, \\ J1 Percetakan Negara, Jakarta, Indonesia \\ ${ }^{3}$ Department of Pathology, Faculty of Medicine, University of Indonesia, \\ Jl Salemba Raya No 6, Jakarta, Indonesia
}

\begin{abstract}
Problem statement: Malaria caused by various species of prozoan parasites, Plasmodium. The exact mechanism of humoral immunity in eliminating Plasmodium is not completely understood. However, an antimalarial antibody is strongly suspected to play important role in immunity. The purpose of this research was to evaluate the immunomodulator and antiplasmodial activities of Indonesian propolis extracts. Approach: Thirty male BALB/c mice weighing approximately 25-30 g aged between 6 and 8 weeks old were used for propolis treatment in vivo. The mice infected with $0.1 \mathrm{~mL}$ of the $P$. berghei suspension at a concentration of $10^{7}$ parasites per mouse on day 0 . The drug was administered orally for 4 days from day $0-3$ at doses 25,50 and $100 \mathrm{mg} \mathrm{kg}^{-1} \mathrm{BW}$ in the experimental group. The control group was given the solven in equal volume for the same duration. This research utilized not only hypersensitivity reaction which measures the humoral immunity by SRBC-immunized mice but also the activity and capacity of peritoneum macrophage phagocytosis in Plasmodium berghei-infected mice. The parasitaemia number was calculated using blood smear method every day for 4 day after the mice had been infected $P$. berghei to identify the antiplasmodial activity. Results: The research results revealed that Propolis Hydroalcoholic Solution (PHS) had a strong immunomodulatory activity but weak antiplasmodial activity. Conclusion: It was concluded that PHS showed more immunostimulant activity than antiplasmodial activity, proved by the increase of IgG and the macrophage phagocytosis activity and capacity. The antiplasmodial activity of PHS was due to the mice immunity increase so that they lived longer.
\end{abstract}

Key words: Propolis, immunomodulator, antiplasmodial

\section{INTRODUCTION}

Propolis (bee glue) is a dark-colored resinous substance collected by bees from poplar buds and other plants and used to seal their hives ${ }^{[1]}$. More than 180 propolis constituents have been identified by Gas Chromatography-Mass Spectrometry (GC-MS). These compounds can be grouped as follows: free aromatic acids; flavonoids; benzyl, methylbutenyl, phenylethyl, cinnamyl and other esters of these acids; chalcones and dihydrochalcones; terpenoids and others such as sugars, ketones, alcohols ${ }^{[2,3]}$. Although in small quantities, these compounds can be very important to propolis $\operatorname{activity}^{[4]}$.

It has been used in folk medicine since ancient times and its now known to be a natural medicine with antibacterial, antifungal, antitumoral, antioxidative, immunomodulatory and other beneficial activities ${ }^{[5]}$. Although there is much research about propolis, the data of propolis for antiplasmodial activity which are mainly related to its immunomodulator effect do not exist. The purpose of this research is to examine the antiplasmodial and immunomodulator effects of Indonesian propolis. It is expected that propolis may be utilized as antimalarial drugs as well as its immunomodulator effect. The effect of propolis on the immune system has also been investigated by some authors, who showed its ability to activate macrophages ${ }^{[6,7]}$ and stimulate antibody production by SRBC-immunized mice ${ }^{[8]}$. The exact mechanism of humoral immunity in eliminating plasmodium is not completely understood. However, an antimalarial

Corresponding Author: Syamsudin, Department of Pharmacology, Faculty of Pharmacy, Pancasila University, Jl. Srengseng Sawah, Jagakarsa, Jakarta 12460, Indonesia 
antibody is strongly suspected to play important role in immunity. The aim of this study was to evaluate the antiplasmodial and immunomodulatory activities of propolis.

\section{MATERIALS AND METHODS}

Propolis hydroalcoholic solution: Propolis was produced by Cibubur honeybees from the apiary located on Lawang (East Java, Indonesia). A 30\% propolis ethanolic solution was prepared. A week later, this solution was filtered and used to prepare a $10 \%$ Propolis Hydroalcoholic Solution (PHS).

Animals: Thirty male BALB/c mice weighing approximately 25-30 g aged between 6 and 8 weeks old were used for propolis treatment in vivo. The mice infected with $0.1 \mathrm{~mL}$ of the $P$. berghei suspension at a concentration of $10^{7}$ parasites per mouse on day 0 . The drug was administered orally for 4 days from day 0-3 at doses 25,50 and $100 \mathrm{mg} \mathrm{kg}^{-1} \mathrm{BW}$ in the experimental group. The control group was given the solven in equal volume for the same duration ${ }^{[9]}$. During the experimental period, the animals were housed under standard laboratory conditions with ad libitum water and balanced food.

No of parasitaemia analysis: The methods of Giemsa blood smear was used to count the number of the parasites. The blood in the periphery was taken from the tails of mice and prepared to a sample of thin and thick smeared blood method with Giemsa coloring. The number of parasitemia was calculated by determining the percentage of red blood cells infected by $P$. berghei in 5000 red blood cells ${ }^{[10]}$.

Macrophage of phagocytocyte analysis: The test of non-specific phagocytosys activity was conducted in vitro, in reference to Leijh et al. ${ }^{[11]}$ using latex particles with the diameter of $3 \mu \mathrm{m}$. The latex particles were resuspended in PBS to obtain the concentration of $2.5 \times 10^{7} \mathrm{~mL}^{-1}$. Peritoneum macrophages, cultured a day before, were washed twice in the RPMI medium and then added with latex suspension of $200 \mu \mathrm{L}$ well ${ }^{-1}$ and incubated in a $\mathrm{CO}_{2} 5 \%$ incubator, $37^{\circ} \mathrm{C}$, for about $60 \mathrm{~min}$. After that, the cells were washed with PBS $3 \mathrm{X}$ to remove the unphagocytosysed particles, dried in the room temperature and fixated with absolute methanol. Once dried, the cells attached to the cover slip were colored with Giemsa 20\%. The percentage of cells phagocytizing latex particles and the number of phagocytized latex particles were counted from
100 cells, using a light microscope with the zoom of $400 \mathrm{x}^{[11]}$.

Hypersensitivity reaction which measures the humoral immunity: The PHS (in doses of 25, 50 and $100 \mathrm{mg} \mathrm{kg}^{-1}$, body weight) was administered to the animals (test group) orally for five days and the vehicle was administered to the control animals. Each group consisted of five mice. The mice were immunized by injecting 0 and $5 \mathrm{~mL}$ of SRBCs intraperitoneally (i.p) on the day of the immunization. Blood samples were collected by retro-orbital puncture on the tenth day after immunization. Antibody levels were determined by the hemagglutination technique ${ }^{[12]}$. The antibody titer was determined by a two-fold serial dilution of one volume $100 \mu \mathrm{L}$ of serum and one volume $100 \mu \mathrm{L}$ of $0,1 \%$ SRBCs in BSA in saline was added and the tubes were mixed thoroughly. They were allowed to settle at room temperature for about $60-90 \mathrm{~min}$ until the control tube showed a negative pattern. The value of the highest serum dilution showing visible hemaglutination was taken as the antibody titer.

\section{RESULTS}

From the research results shown on Table 1, we can see that the group of mice PHS-administered in the dosage of $100 \mathrm{mg} \mathrm{kg}^{-1} \mathrm{BW}$ has higher IgG concentration than those in the dosage of 25 and $50 \mathrm{mg} \mathrm{kg}^{-1} \mathrm{BW}$. With regards to the humoral immune response, the ethanolic extract of propolis $500 \mu \mathrm{g}$ mouse $^{-1}$ increases the antibody production in Sheep Red Blood Cells (SRBC)immunized mice ${ }^{[13]}$.

The phagocitosys response includes the phagocytosis activity (the number of active phagocyt in 100 phagocyt cells) and phagocyt capacity (the number of phagocytized plasmodium in 50 active phagocyt cells.

Table 2 shows the PHS effect on the activity and phagocytosis capacity of the macrophages. The statistical test show that the treated groups (doses 25, 50 and $100 \mathrm{mg} \mathrm{kg}^{-1}$ of b.wt) are significantly different from the control group.

Table 1: Hemagglutination antibody titer of Propolis Hydroalcoholic Solution (PHS)

\begin{tabular}{lll}
\hline $\begin{array}{l}\text { Successive } \\
\text { ethanol extract } \\
\left(\mathrm{mg} \mathrm{kg}^{-1} \cdot \mathrm{p} . \mathrm{o}\right)\end{array}$ & $\begin{array}{l}\text { Hemagglutination antibody titer } \\
-\mathrm{-} \text { days }(\text { mean } \pm \mathrm{SD})\end{array}$ & 15 days $($ meant $\pm \mathrm{SD})$ \\
\hline 25 & $3951 \pm 209,05$ & $4358 \pm 152,85$ \\
50 & $4270 \pm 220,91^{*}$ & $4779 \pm 172,06^{*}$ \\
100 & $5152 \pm 263,73^{*}$ & $5860 \pm 313,32^{*}$ \\
Control & $3951 \pm 162,63$ & $4182 \pm 213,07$ \\
\hline
\end{tabular}

Values are mean $\pm \mathrm{SD}, \mathrm{n}=5$ in each group, *: $\mathrm{p}<0.05$ when compared with control group 
Am. J. Pharm. \& Toxicol., 4 (3):75-79, 2009

Table 2: Effect of Propolis Hydroalcoholic Solution (PHS) treatment to mice on phagocytosis by peritoneum macrophages

\begin{tabular}{lll}
\hline Propolis hydroalcoholic solution $\left(\mathrm{mg} \mathrm{kg}^{-1}\right.$ of b.wt) & No of macrophages mice- $10^{6}$ & Phagocytosis $(\%)$ \\
\hline 25 & $30,27 \pm 3,41^{*}$ & $162,06 \pm 5,47^{*}$ \\
50 & $39,50 \pm 2,47^{*}$ & $351,50 \pm 4,98^{*}$ \\
100 & $45,07 \pm 3,54^{*}$ & $440,33 \pm 5,89^{*}$ \\
Control & $25,07 \pm 2,33$ & $115,50 \pm 4,87$ \\
\hline
\end{tabular}

Values are mean $\pm \mathrm{SD}, \mathrm{n}=5$ in each group, $*$ : $\mathrm{p}<0.05$ when compared with control group

Table 3: Percent parasitemia in P. berghei infected mice after 4 days of treatment from Propolis Hydroalcoholic Solution (PHS)

\begin{tabular}{|c|c|c|c|c|c|c|}
\hline \multirow[b]{2}{*}{ Treatment } & \multirow{2}{*}{$\begin{array}{l}\text { Dose } \\
\left(\mathrm{mg} \mathrm{Kg}^{-1} \text { of }\right. \\
\left.\text { b. wt day }{ }^{-1}\right)\end{array}$} & \multirow{2}{*}{$\begin{array}{l}\text { No. of } \\
\text { mice tested }\end{array}$} & \multicolumn{4}{|c|}{ Percentage of parasitemia (mean \pm SD) on the following day after treatment } \\
\hline & & & D1 & $\mathrm{D} 2$ & D3 & D4 \\
\hline \multirow[t]{3}{*}{$\overline{\mathrm{PHS}}$} & 25 & 6 & $10.51 \pm 1.48$ & $8.39 \pm 1.36$ & $7.75 \pm 1.31$ & $6.41 \pm 1.48$ \\
\hline & 50 & 6 & $9.830 \pm 1.33$ & $8.31 \pm 1.49$ & $7.41 \pm 1.25$ & $6.87 \pm 1.49$ \\
\hline & 100 & 6 & $9.860 \pm 1.48$ & $6.10 \pm 1.41$ & $5.10 \pm 1.41$ & $4.08 \pm 1.10$ \\
\hline Chloroquine & 10 & 6 & $10.41 \pm 1.29$ & $9.56 \pm 1.28$ & $5.13 \pm 1.46$ & $1.43 \pm 1.51$ \\
\hline
\end{tabular}

The activity and phagocytosis capacity of the macrophages increase proportional to be doses. The activity and phagocytosis capacity of the macrophages at the PHS dose of $100 \mathrm{mg} \mathrm{kg}^{-1}$ of b.wt is higher than those at the dose of 25 and $50 \mathrm{mg} \mathrm{kg}^{-1}$ of b.wt.

Table 3 shows that the percentage of parasitemia in $P$. berghei infected mice after 4 days of treatment from PHS. The percentage of parasitemia decreases proportional to the length of observation (D1-D4). At the dose of $100 \mathrm{mg} \mathrm{kg}^{-1}$ of b.wt on day the percentage of parasitemia is $4.08 \pm 1.10$, smaller than that $(6.87 \pm 1.49)$ at the dose of $50 \mathrm{mg} \mathrm{kg}^{-1}$ of b.wt. Similarly, it is smaller than the percentage of parasitemia (6.41 \pm 1.48$)$ at the dose of $25 \mathrm{mg} \mathrm{kg}{ }^{-1}$ of b.wt. Compared to chloroquine as the standard antimalarial drug, the parasitemia percentage is $1.43 \pm 1.51$ on day, significantly different from chloroquine.

\section{DISCUSSION}

The functional immune response occurs when the parasites undergo asexual erythrocitic phase. As soon as the parasites enter the red-blood cells, the antibody can be detected using conventional serology method.

Recent reports indicate that several types of flavonols stimulate human perpheral blood leukocyte proliferation. They significantly increase the activity of helper $\mathrm{T}$ cells, cytokines, interleukine 2, $\gamma$-interferon and macrophages and are thereby useful in the treatment of several diseases caused by immune dysfunction ${ }^{[19]}$. The chemical profile of propolis can be characterized by three parameters: total flavone and flavonol content, total flavanone and dihydroflavonol content and total phenolic content ${ }^{[20]}$. It is thus apparent that the immunostimulatory effect produced by the PHS containing flavonoids, may be due to cell mediated and humoral antibody mediated immune response.
Macrophages as the trigger in the cellular immune system play a role in the eradication of plasmodium, mainly in the erithrocyt stage. After the macrophages are activated by gamma interferon (IFN $\gamma$ ) produced by native $\mathrm{T}$, they change into phagocyte to do the phagocytosys, to eliminate the parasites ${ }^{[14,15]}$. The macrophage phagocytosys activities could be activated with the administration of imunostimulant drugs, not only in the form of vaccine but also certain natural chemicals ${ }^{[16]}$. The primary target of most of the immunomodulatory compound is believed to be the macrophages which play a key role in the generation of an immune response ${ }^{[17]}$.

The phagocytosis activity and capacity of propolis extract in the dosage of $100 \mathrm{mg} \mathrm{kg}^{-1} \mathrm{BW}$ day ${ }^{-1}$ is higher than those in the dosage of 50 and $25 \mathrm{mg} \mathrm{kg}^{-1} \mathrm{BW}$ might be caused by the chemical components in the active fraction stimulating the limphocyt cells to mature and self-divide into lymphocyt $\mathrm{B}$ and $\mathrm{T}$ producing limfokin (cytocin/interleucine) to keep macrophage active. Not only can the activated macrophage produce lisozyme enzym and the complements, but also increase their capacity to kill through the phagocytosys process on the plasmodium. In the control group, the activity of phagocyt cells was low because the phagocyt cells were not induced.

Lymph as one of the secondary organs also plays important role in supporting body defense. By transferring lymphatic cells from $P$. berghei-immune mice to recipients, all parasites were eradicated relatively fast. Under the $P$. berghei-infected condition, the lymph sizes of the mice in negative control group were larger than those in normal mice and PHSadministered mice. The increase of lymph weight in the mice of control negative mice was probably due to the increase of erythropoietic activity in the lymph. During malarial infection the number of infected erythrocytes 
multiplies 8 times every $48 \mathrm{~h}$ and all of them will be destroyed when the schizonts breaks out. The lost of these numerous erytrocytes triggers the bone marrow to produce new ones ${ }^{[18]}$.

As the mice were infected by $P$. berghei, the parasitaemia increase (Table 3 ) since the body immune response was not quite perfect and the parasites were still phagocytosized slowly mainly in lymph. A lot of infected erythrocytes were found in lymph and phagocytosis by macrofage. The phagocytosis on IgGsensitized cells and C3b-attached cells by the lymphatic macrofages of infected mice was higher than that of normal mice. Plasmodium berghei is a synchronized parasite target erythrocytes infected by young parasites might not cause the change of erythrocyte membrane surface. Lymph macrofages activated by malarial infection may phagocytosize those. The factor increasing infected-erythrocytes phagocytosis is macrofage activation. Free parasites and full-grown erythrocytes are targets of phagocytosis because they express surface antigens against serum ${ }^{[21]}$. The Table 3 reveals that PHS administered showed weaker antiplasmodial activity than chloroquine dose. On the other hand, Dantas et al. ${ }^{[22]}$ investigated that effects of Bulgarian propolis (25 and $50 \mathrm{mg} \mathrm{kg}^{-1}$ ) in the experimental model of Trypanosoma cruzi-infected Swiss mice, verifying that this bee product led to a decrease in parasitemia and showed no hepatic or renal toxic effect ${ }^{[22]}$.

\section{CONCLUSION}

Propolis Hydroalcoholic Solution (PHS) showed more immunostimulant activity than antiplasmodial activity, proved by the increase of $\mathrm{IgG}$ and the macrofage phagocytosis activity and capacity in the dosages of 25,50 and $100 \mathrm{mg} \mathrm{kg}^{-1} \mathrm{BW}$. The antiplasmodial activity of PHS was due to the mice immunity increase so that they lived longer.

\section{REFERENCES}

1. Bankova, V., R. Christov, A. Kujumgiev, M.C. Marcucci and S. Popov, 1995. Chemical composition and antibacterial activity of Brazilian propolis. Z. Naturforsch, 50: 167-172. http://www.ncbi.nlm.nih.gov/pubmed/7766255

2. Bankova, V., A. Dyulgerov, S. Popov, L. Evstatieva, L. Kuleva, O. Pureb and Z. Zamjansan, 1992. Propolis produced in Bulgaria and Mongolia: Phenolic compounds and plant origin. Apidologie, 23: 79-85.

http://www.apidologie.org/index.php?option=article\&ac cess=standard \&Itemid=129\&url=/articles/apido/pdf/199 2/01/Apidologie_0044-8435_1992_23_1_ART0009.pdf
3. Greenaway, W., J. Maj, T. Saysbrook and F.R. Whatley, 1991. Identification by gas chromatography-mass spectrometry of 150 compounds in propolis. Z. Naturforsch, 46: 111-21.

4. Bankova, V., A. Dyulgerov, S. Popov and N. Marekov, 1987. A GC/MS study of the propolis phenolic constituents. Z. Naturforsch, 42: 147-151. http://cat.inist.fr/?aModele $=$ afficheN\&cpsidt $=8152$ 158

5. Burdock, G.A., 1998. Review of the biological properties and toxicity of bee propolis. Food Chem. Toxicol., 36: 347-363. DOI: 10.1016/S02786915(97)00145-2

6. Dimov, V., N. Ivanovska, N. Manolova, V. Bankova, N. Nikolov and S. Popov, 1991. Immunomodulatory action of propolis. Influence on anti-infectious protection and macrophage function. Apidologie, 22: 155-162.

http://cat.inist.fr/?aModele $=$ afficheN\&cpsidt $=4997$ 560

7. Orsi, R.O., S.R.C. Funari, A.M.V.C. Soares, S.A. Calvi, S.L. Oliveira, J.M. Sforcin and V. Bankova, 2000. Immunomodulatory action of propolis on macrophage activation. J. Venom. Anim. Toxins., 6: 205-19. DOI: $10.1590 /$ S010479302000000200006

8. Scheller, S., G. Gazda, G. Pietsz, J. Gabrys, J. Szumlas, L. Eckert and J. Shani, 1988. The ability of ethanol extract of propolis to stimulate plaque formation in immunized mouse spleen cells. Pharmacol. Res. Commun., 20: 323-328.

http://grande.nal.usda.gov/ibids/index.php?mode2= detail\&origin=ibids_references\&therow $=515814$

9. Peters, W., 1987. Chemotherapy and Drugs Resistance in Malaria. Academic Press, Inc., New York, ISBN: 978012552, pp: 145-273.

10. Markell, E.K., M. Voge and D.T. John, 1987. Medical Parasitology. 6th Edn., W.B. Saunders Company, Philadelphia, ISBN: 0-7216-76340.

11. Leijh, P.C.J., R.V. Furth and T.L.V. Zwe, 1986. In Vitro Determination of Phagocytosis and Intracellular Killing by Polymorphonuclear and Mononuclear Phagocytes. In: Cellular Immunology, Weir, D.M. (Ed.). Blackwell Scientific Publication, London, pp: 74-85.

12. Nelson, D.S. and P. Mildenhall, 1967. Studies on cytophilic antibodies. The production by mice of macrophage cytophilic antibodies to sheep erythrocytes: Relationship to the production of other antibodies and the development of delayed type hypersensitivity. Aust. J. Exp. Biol. Med. Sci., 45: 113-30. http://www.ncbi.nlm.nih.gov/pubmed/6029846 
13. Scheller, S., G. Gazda, G. Piettsz, J. Gabrys, J. Szumlas, L. Eckert and J. Shanni, 1988. The ability of ethanol extract of propolis to stimulate plaque formation in immunized mouse spleen cells. Pharmacol. Res. Commun., 20: 323-328. http://grande.nal.usda.gov/ibids/index.php?mode2= detail\&origin=ibids_references\&therow $=515814$

14. Abbas, A.K., A.H. Lichtman and J.S. Pober, 1994. Celluler and Molecular Immunology. 2nd Edn., Philadelphia, W.B. Sounders Company. ISBN: 9780721655055

15. Yaneto, T., T. Yoshimoto, C.R. Wang, Y. Takahama, M. Tsuji, S. Waki and Nariuchi, 1999. Gamma interferon production is critical for protective immunity to infection with blood-stage $P$. berghei XAT but neither NO production nor NK cell activation is critical. Infect. Immunity, 67: 234956. DOI: 0019-9567/99/804.00.0

16. Subramaniam, A., D.A. Evans, S. Rajasekharan and P. Puspangadan, 2000. Effect of Trichopus zeylanicus Gaertn (active fraction) on phagocytosis by peritoneal macrophages and humoral immune in response in mice. Ind. J. Pharmacol., 32: 221-225. http://www.ijp-online.com/article.asp?issn=02537613; year $=2000 ;$ volume $=32 ;$ issue $=3 ;$ spage $=221$; ep age $=225$; aulast $=$ Subramoniam; type $=0$

17. Kaslow, D.C., 1990. Immunogenicity of Plasmodium falciparum sexual stage antigens implications for the design of a transmission blocking vaccine. Immunol. Lett., 25: 83-86. http://www.ncbi.nlm.nih.gov/pubmed/1704352
18. Nardin, E.H. and R.S. Nussenzweig, 1993. T cell responses to pre erythrocytic stages of malaria role in protection and vaccine development against preerythrocytic stages. Ann. Rev. Immunol., 11: 687727. DOI: 10.1146/annurev.iy.11.040193.003351.

19. Kawakita, S.W., H.S. Giedlin and K. Nomoto, 2005. Immunomodulators from higher plants. J. Nat. Med., 46: 34-38.

20. Popova, M., V. Bankova, D. Butovska, V. Petkov, B. Nikolova-Damyanova, A.G. Sabatiai, G.L. Marcazza and S. Bogdanov, 2004. Validated methods for quantification of biologically active constituents of poplar type propolis. Phytochem. Anal., 15: 235-240. DOI: $10.1002 /$ pca 777

21. Shear, H.L., 1989. The Role of Macrophages in Resistance to Malaria. In: Malaria: Host Responses to Infection, Stevenson, M.M. (Ed.). CRC Press, Boca Raton Florida, ISBN: 9780849347450, pp: 87-108.

22. Dantas, A.P., B.P. Olivieri, F.H.M. Gomes and S.L. De Castro, 2006. Treatment of Trypanosoma cruzi-infected mice with propolis promotes changes in the immune response. J. Ethnopharmacol., 103: 187-193. DOI: 10.1016/j.jep.2005.07.018 